\title{
Pyric Other, Pyric Double: Fire Tame, Fire Feral, Fire Extinct
}

\author{
Stephen J. Pyne
}

Editors' note: Meteorologists are telling us that La Niña will soon loosen her grip on Australia, and as El Niño gathers strength, we are likely to be entering the period of drought and - inevitably - fire. With this in mind, we asked Stephen Pyne to write an essay about fire in both its loved and unloved personae.

$\S$ Fire is not animate. Most scientists would define it simply as a chemical reaction shaped by its physical surroundings. To regard it as an 'other', loved or unloved, or to speculate accordingly about its survival or extinction would seem preposterous. One might as well contemplate the lovedness of carbonic acid or the extinction of rust.

Yet, while not living, fire is a creation of the living world, and shares many of life's traits. Life creates and sustains fire's existence: life supplies the oxygen it breathes, life furnishes the fuels that feed it, and life, in the hands of people, overwhelmingly applies the ignition that sparks it into existence. The core reaction itself is a central bio-chemical process that takes apart what photosynthesis puts together. When that occurs within a cell, it's called respiration; when it happens in the wide world, fire. Because it is an event, not a substance, fire takes its character from its context. It is what its circumstances make it. Those circumstances are largely biotic, pruned by considerations of terrain and weather, and increasingly, they are cultural.

Its alliance with humanity is equally binding. For, while fire has existed on Earth for at least 420 million years, its geography and dynamics have, over the course of the Holocene, aligned more and more closely with those of Homo sapiens. Its importance for people is obvious, recorded endlessly in fire myths: fire made humanity what it is, fire lofted people above their cringing status as hapless scroungers to the top of the food chain. All people have fire, and only people. All our existence humanity has, in fact, enjoyed a species monopoly over fire's manipulation. Equally, humans have projected fire well beyond the spaces and times allotted by nature. Fire now thrives in places that are otherwise too wet or too dry, or that lack ignition. The relationship has become a symbiosis, with fire as folded into human culture as completely as the Krebs cycle into cells.

$\S$ People have long treated fire as though it were alive, and granted it standing as a symbol of life. Fire is considered living, or dead. It's kindled: 'kindle' has the same etymological origins as 'kin.' It's tended, as we do gardens and children. 
It's domesticated, perhaps our founding act of domestication. (The domus is often primarily for the fire, secondarily for people.) The hearth defines the social unit; a family consists of those who share a fireside, the vestal fire is the family fire written on the scale of the state. The family gods are those of the hearth. The tamed fire - the fire in hearth and furnace - is among the most comforting of presences and the most reassuring of emblems. And while not loved per se, fire often stands for love's desires, flaring passionately into flame, or subsiding into dying embers.

Perhaps fire's closest analogues among creatures are those that endure in both domesticated and wild variants. The ideal might be the dog and wolf. The wild species, the wolf, can exist apart from humanity, and even compete with or threaten people. But the tame species, the dog, is an ancient companion, likely humanity's first, and one content to lie by a fire. Both fire and dog must be cared for: nurtured, taught, put to use as an extension of humanity's power. The many breeds of the dog emulate the many calculated expressions of fire: fire as candle, as stove, as heating appliance, as celebratory bonfire, as cleansing burn; the permutations seem endless. And as the domesticated may turn rabid - the tame turn feral - so it is with fire. The danger is real. Societies expend enormous efforts to prevent such accidents (or perversions of the norm) from happening.

Mostly, the tame drives out the wild. The controlled burn replaces the savage. As societies advance technologically, they further refine the process by distilling the fuels, and even the air, into those components that are critical to sustain combustion. Instead of burning wood or straw in a field, they burn wax, diesel or natural gas in candles or combustion chambers. In aboriginal societies, early burning can reclaim landscapes from natural fires; in agricultural settings, fallow burning and cleaning fires replace loosed flames, as the tamed landscape supports tamed burning. In industrial societies even those domesticated fields are gone, and open flame becomes anathema, save in its most confined and symbolic forms, at most a kind of house pet. The only wild fires urbanites in developed countries are likely to see are feral fires from accident, arson, and war, or in virtual forms on television screens.

In this way the saga of fire resembles that of species. In its loved forms - tamed, a tool, a servant, a companion - it has thrived. In its unloved forms - wild, fickle, a dangerous trickster - it has been driven away; in many settings banished into exile. In industrial societies it has vanished from quotidian life. As concerns over global warming accelerate, this trend will likely intensify. It is, after all, humanity's combustion habits, particularly the replacement of open fire by internal combustion, and the consequent appeal to vast quantities of fossil fuel, that is unhinging the natural rhythms of climate. The free-burning fire, extravagant in its consumption of combustibles and its release of carbon, will 
likely be further vilified. The fireplace may join the SUV as a symbol of human fecklessness. The politics of climate may deem open burning too dangerous to leave in the hands of ordinary folk.

$\S$ Over much of planet Earth fire is not in imminent danger of extinction. Lightning still kindles fire aplenty; swidden farmers routinely light fires to clear new plots, and sedentary farmers burn off fallow in regular cycles; graziers set fires as they come and go from distant pastures; fires break free from controlled settings, and run amok. The Earth is an inextinguishably fire planet. Fire will not disappear until life does.

But it is clear that the current dimensions of fire's geography are set by people, and as people alter their relationship to land so fire will wax and wane. The Holocene has been by and large a time of waxing, as people created favorable circumstances for fire and took their firesticks everywhere. The past century has trended toward rapid waning, as industrial combustion substitutes (or suppresses) open burning. If political measures to contain such combustion as a global threat work, they may lead to a mass replacement of burning of all kinds by sources of power that do not depend on combustion at all. The welldocumented decarbonization of energy will make open flame seem even more of a luxury, an embarrassment, and a menace.

There is, however, one grand exception. As industrial societies have established nature preserves, they have created, if inadvertently, habitats for free-burning flame. In fact, much of the impetus for state-sponsored conservation was to protect those lands from abusive burning. Over time, on those sites that had enjoyed a long history of fire, fire proved immune to suppression, but the sheer attempt to remove it proved ecologically destabilizing. More fuels built up, which led to more savage wild fires; flora and fauna that had adapted to particular regimes of burning now found themselves disadvantaged by fire's removal, or its abrupt transfiguration into more virulent forms. Over and again, nature preserves have found themselves with too much of the wrong kind of fire and not enough of the right.

For several decades, the thrust of policy has been to reinstate fire so it can do the biological work required. There is little argument that fire belongs: the issue is how to do it. Here - even amid what is ostensibly a simple case of restoring wild nature to wild settings - the task has proved vexing. Can we really let wild fire loose? There is little reason to believe flame will remain in its designated preserves, much less its smoke. Are the historic fire regimes the result of nature alone? What about tens of thousands of years of human burning? Should some kind of prescribed burning substitute, or does such obvious manipulation violate the pristine character sought for the protected site? How can reinstigating fire be carbon neutral? Here again fire resembles an organism: it will thrive or 
fail depending on its habitat. It will synthesize its surroundings. If those are suitable, fire will do the ecological work desired. If not, not. The issue is not simply putting fire back in, but establishing the context by which it can thrive as we wish.

$\S$ The flip side to restored fire is the surprising revival of wild fire, often on an immense scale. The blame is instinctively placed on global warming; and of course, hot, dry, and windy provides better conditions for burning than cold, wet, and calm. But the underlying dynamics most closely track land use. In this regard, megafires - or megaburning - afflicts both developed and developing nations. In the latter, it accompanies large scale land-clearing; in the former, a massive reconstitution of land use either from abandoned agricultural lands, or from exurban colonization of formerly rural lands, or from the transfer of land to state-sponsored reserves. Here again blame is placed on past practices, notably, fire suppression (or more properly, fire exclusion), which allowed combustibles to stockpile in unnatural caches.

In fact, fire practices are a culprit, but not just those benighted policies of the past. The reclassification of lands for nature preserves is a contributing cause since it has not merely promoted fire but has preferentially encouraged quasiwild fire. This has boosted burned area - exactly what policy says it wanted. At the same time there is a willingness to tolerate more burning for its ecological benefits and an unwillingness to place firefighters at risk for remote or dubious assets, both of which have also expanded the amount of land burned. It's the trilogy, contemporary fire's new triangle - suitable weather, land use that fluffs the scene with combustibles, and fire practices - that account for the scale of burning and its appearance in nations otherwise committed to industrial combustion.

In truth, the three causes are related, and all have as their nuclear core humanity. People oversee the reformation in lands (and their surface fuels); people decide where, when, and how to light fires and fight them; and people are perturbing climate in ways that appear to promote more open burning. Bad burning practices, it would seem, thus lead to even more bad burns. The belief by statesponsored forestry that it had fire bottled up may be correct, but it turns out that it was a Klein bottle.

$\S$ Fire: feared, savoured, loathed, loved, suppressed, encouraged, soughtafter, tolerated, cherished. Like all human categories, fire slips readily into dichotomies. (In his analysis of this human propensity, Claude Levi-Strauss used fire as his foundational exemplar, with the world partitioned into the raw and the cooked.) But more than most phenomena, fire ranges widely through human judgments and sentiments. It is not something we encountered after our formative identity was forged: it was with us, a species heritage, from the 
beginning. It is possible to imagine fire without humanity. It is impossible to imagine humanity without fire. Over tens of millennia, our ancient alliance has ripened into symbiosis, until today Earthly fire, while inextinguishable, is all but inextricable from humanity. Each is what it is because of the other. Each has become an odd mirror to the other.

This is worth repeating: fire is what its circumstances make it. And since humanity has become the primary agent, directly and indirectly, of setting fire's circumstances, the pyric Other that is fire is also a pyric Double. It shows ourselves in its flames. The unloved Other of fire is our unloved Self.

Steve Pyne is a historian and resident pyromantic in the School of Life Sciences at Arizona State University, Tempe, Arizona, USA. He has written numerous books on the history of fire, environmental history, and the history of exploration. 
